\title{
A Proposed Perspective for Developing Science Curriculum for the Upper Primary Grades in accordance to Saudi Arabia's Vision for 2030: An Analytical and Descriptive Study according to Delphi Method
}

\author{
Abdulqadir Obaidallah A. Alhomairi ${ }^{1}$ \\ ${ }^{1}$ Department of Curriculum and Methods of Instruction, University of Tabuk, Saudi Arabia \\ Correspondence: Abdulqadir Obaidallah A. Alhomairi, Department of Curriculum and Methods of Instruction, \\ University of Tabuk, Saudi Arabia \\ Received: December 23, 2017 \\ Accepted: January 9, 2018 \\ Online Published: January 26, 2018 \\ doi:10.5430/ijhe.v7n1p69 \\ URL: https://doi.org/10.5430/ijhe.v7n1p69
}

\begin{abstract}
Saudi Arabia's Vision for 2030 in development is exceedingly concerned with curriculum development. It believes that the current curriculum does no longer support the students' preparation for both life and work. Therefore, the present study aimed to reach a consensus by a set of educational experts on the importance of providing the science curriculum for the fifth and sixth primary grades with a content that can help achieve the requirements of the Kingdom's Vision for 2030 in development. In addition, it aimed to study what perceptions these educational experts have towards developing the science curriculum that can better achieve this vision. The study followed the descriptive approach and the use of Delphi method. It was applied to a group of (28) educational experts over three rounds that started on October 8, and ended on November 9, 2017. Findings indicated that the provision degree of the requirements of Saudi Arabia's Vision for 2030 to develop the science curriculum for the upper primary grades was too weak. Responses of educational experts concerning developing the science curriculum to achieve the requirements of this vision, at the end of the third round, ranged between strongly agree and agree. At the end, a perspective for the development of the science curriculum was proposed depending on the viewpoints of the educational experts who participated in the present study.
\end{abstract}

Keywords: Saudi Arabia's Vision for 2030, Development of science curriculum, Primary grades, University of Tabuk

\section{Introduction}

The announcement of Saudi Arabia's Vision for 2030 keeps pace with the mission of education and concurrently, supports its march in order to build a new generation that is capable to assume responsibility and make decisions. Therefore, Saudi Arabia's Vision for 2030 has been launched to achieve a set of aims. It, for instance, aims to provide all people with many opportunities of an outstanding learning; to improve the quality and outcomes of learning; to upgrade the skills and abilities of the employees of education; and encourage innovation and creation; and to develop curriculum (Saudi Arabia's Vision for 2030, 2017) because it is the heart of education (Seyyedezaie \& Barani, 2013). Curriculum is the main resource for achieving education aims like qualifying the individuals who can benefit themselves and their society and be able to assume responsibility and achieve comprehensive development in their societies (Abdul Salam, 2006).

Curriculum is the element that affects and, in the same time, be affected by current changes. Work force development depends on curriculum to meet these changes. On the other part, curriculum is a means to meet the goals of education in all phases. Development and prosperity are achieved as far as the elements of power are included in curriculum and as far as they take into account the demands of students (Baltiyah \& Metwally, 2000). Science curriculum development is a continuous and important process to keep up with the contemporary global developments (Abdul Hamid, 2016). Many global projects that have been guided towards this aim include:

1. The Science Curriculum Reform in light of interaction among science, technology and society, (Al Shaya \& $\mathrm{Al}$ Aqeel, 2006);

2. The (2061) project of (AAAS) American Association for the Advancement of Science;

3. The project of (NSES) National Science Education Standards; 
4. the project of Saudi Mathematics and Natural Science Curriculum Development that aims to adapt the distinguished global series like McGraw-Hill to all phases of public education (Al Zughaybi, 2011); and

5. The (2061) project for the Dissemination of Scientific Culture and the use of modern technology in the development of science teaching, (Hassanein, 2014).

In addition, many Arabic studies and researches have provided other developmental visions for the science curriculum, like for example (Al Ghayyadh, 2003); (Mohammed, 2012); (Shalabi, 2014); and (Foudeh \& Ghanem, 2015). The challenge to develop the science curriculum in education continues to exist. The construction of curriculum and the design of the teaching materials are the most important challenges. Diagnosis of the current outputs reveals the dominance of indoctrination and the lack of interest in building learners' mental abilities and scientific skills. Diagnosis also shows the limited use of modern theories and trends in science education, (Al Oweysheq \& Ahmed, 2010). Therefore, Saudi Ministry of Education should adopt a fresh and different system that focuses on the curriculum quality not quantity, which is compatible with the era necessities in achieving the developmental and economic goals (Al Ali, 2016). This development process should be continuous and comprehensive for all curriculum elements and components. It should be also associated with societies to achieve the development requirements in light of Saudi Arabia's Vision for 2030.

In brief, the present study aims to identify the provision reality of the requirements of Saudi Arabia's Vision for 2030 to develop the science curriculum for upper primary grades from the viewpoint of the educational experts. In addition, it aims to identify what proposals these experts have to develop the science curriculum to meet the requirements of such a vision.

\subsection{Statement of the Problem}

Indeed, there is a gap between the skills students acquire and the necessities of life and work in our present time. It can be strongly claimed that the curriculum has inadequately prepared students for these two areas. Bybee (2010) revealed that the learning outcomes of present science programs are insufficient for preparing students for life and work. Students are going to face a crisis because they are being prepared for kinds of employment that have disappeared or about to be so. Research has proved that science curriculum at both Arabic and international levels is clearly deficient in preparing learners for life and work in the $21^{\text {st }}$ century (Shalabi, 2014). Therefore, the present study aims to investigate the provision reality of the science curriculum requirements for the upper primary grades in light of Saudi Arabia's Vision for 2030. In addition, it seeks to build a proposed perspective for the science curriculum to meet this Vision.

\subsection{Importance of the Study}

Science education receives international and local attention in terms of developing its curriculum continuously in a way that fits knowledge high acceleration and tremendous development in all fields of science. Natural sciences are directly related to humans in terms of either the environment and its problems, nutrition, production and protection from pollution, or in terms of the need for renewable and clean sources of energy. Natural sciences are also linked to and support the technological progress. Therefore, the development of science curriculum is an urgent need (Al Zubaidi, 2017). Moreover, Saudi Arabia's Vision for 2030, addresses curriculum development and improvement to make education more appropriate for all. It raises the quality of its outcomes and enhances the skills and abilities of its people, which will contribute positively to achieving the development that the Vision for 2030 aims to achieve.

\subsection{Questions of the Study}

The present study aims to provide answers for these two main questions:

How do educational experts perceive the provision reality of the requirements of Saudi Arabia's Vision for 2030 to develop the science curriculum for the upper primary grades?

What perspective do educational experts propose to develop the science curriculum for the upper primary grades to meet the requirements of Saudi Arabia's Vision for 2030 in development?

\section{Theoretical Framework}

\subsection{Saudi Arabia's Vision for 2030}

The World Index of Education has recently shown that, among 187 countries all over the world, Saudi Arabia is in the $34^{\text {th }}$ rank. In 1980, the index was (0.3) and then it began to double until it reached (0.7) in 2017. This increase, of course, predicts that Saudi Arabia is going to occupy an advanced rank during the coming time. Furthermore, Saudi Arabia believes that education is the way of nations towards progress and development. Nations who have neglected 
education are still lagging behind. Therefore, feeling the importance of the role of education, Saudi Arabia has recently adopted an approach to progress through the announcement of its vision for 2030 in development to achieve the following set of aims (Saudi Arabia's Vision for 2030, 2017):

1. provide education opportunities for all in appropriate learning atmospheres,

2. enhance the quality of education outcomes,

3. increase the effectiveness of the scientific research,

4. encourage creativity and innovation,

5. develop partnership with the community,

6. improve the capabilities and skills of education personnel,

7. Bridge the gap between the outcomes of higher education and the requirements of the labor market.

8. Develop public education and guide students towards the appropriate professional options.

9. Provide students with rehabilitation opportunities and flexibility in mobility between different educational tracks.

\subsection{Science Curriculum}

Curriculum has a strategic position in the educational process because it is the practical translation of education aims, plans and trends in each society. It is one main component in the educational system, which consists of aims, content, teaching methods, teaching aids, school activity, and evaluation (Al Abdullah, 2004). Therefore, ministries of education should be highly interested in the processes of developing all curriculum elements, their interdependence, integration and comprehensiveness (Al Bishr \& Al Zahrani, 2004). Curriculum elements, including science curriculum, consist of an integrated and interactive four-core system including the goals (A), content (C), method (M) and evaluation (E) that have been traditionally compiled as a quadratic system of the curriculum in ACME (Zaitoun, 2010).

1. Aims: The main aim of the science curriculum is to provide students with science-related learning experience to develop their scientific knowledge and be able to participate effectively in their rapid change-based society. Besides, science-related experience helps students to work in more profession and science-related areas and then become lifelong learners in science and technology (Curriculum Development Council \& the Hong Kong Examinations and Assessment Authority, 2014).

2. Content: The content of any curriculum is referred to as a set of definitions, concepts, relationships, facts, laws, theories, skills, values, and trends that constitute the learning material in student's textbook at any academic stage. The content is, usually selected and organized according to specific scientific criteria that achieve the curriculum aims (Younis, 2004).

3. Teaching methods: The modern concept of teaching methods indicates the inclusion of all means, procedures, activities and assessment tools that the teacher prepares to achieve the educational aims inside and outside the classroom (Jabir, 2005).

4. Evaluation: Evaluation is a two-dimensional process. The first dimension is limited and targets judging the curriculum structure represented in its scientific and educational content only. It tries to determine the quality and consistency of this content, its ability to achieve the goals and then to modify its weakness points. While the second dimension is more comprehensive and tries to diagnose and treat all curriculum aspects and elements starting from the plan towards objectives, content, teaching methods, educational activities and evaluation through the implementation process (Sayyed \& Salam, 2004).

\subsection{Development of Science Curriculum}

Educational literature includes a variety of models for curriculum development. All of them involve five distinct basic activities that should be carried out in a periodic process starting with analysis, design, development, implementation and ending with evaluation. Each development model often begins with problem analysis, and moves towards context analysis, needs analysis and ends with knowledge base analysis. After that, the first design for development that should be consistent with assessment processes can be established. (Shehata, 2003) \& (Thijs \& Akker, 2009). Childs (2015) mentions that there are, at least, three main models of school science curriculum mainly, the scientific facts and concepts (the content); science nature and processes (the behavior or process); and science applications in society (the context), although each one has its own influence and dominance on the school science. 
Modern curriculum accounts for all models and tries to integrate them in one term known as "science curriculum". Fung, Townsend \& Parr (2004) mention that the integration approach for science curriculum development aims to restructure the traditional way by including the thinking development in the teaching of the curriculum content, i.e. critical thinking. Strategies, such as enculturation to create and maintain a positive social learning environment and collaborative thinking strategy to motivate students' thinking and involve them in the process of thinking with others (peer or teacher- guided discussions) can be used. Abdul Salam $\left(1431^{\mathrm{H}}\right)$ claims that paying attention to developing thinking in curriculum will provide a service for developing the teaching materials and tools and evaluation of students.

\section{Previous Research and Studies}

The need to develop the science curriculum has been emphasized by many studies. Al Ghayyadh (2003), for instance tried to propose a perspective for developing the content of science curriculum in the primary stage in Saudi Arabia in light of modern scientific trends. Mohammed (2012) examined the reality of science curriculum in the primary stage and tried to draw an image of this curriculum in light of scientific topics proposed by global trends. Results showed that students were separated from the current science curriculum and meanwhile the curriculum was separated from their lives. However, it focused on topics that might not reflect their interests and scientific preferences. Results also revealed the inadequacy or shortage of scientific subjects that were of students' concern and preference to study. Al Ghamdi (2012) evaluated the content of developed science textbooks for the elementary grades in light of selected criteria to fit the international experience and experiments. Results showed that the content of the developed science textbooks for the lower primary grades focused on science as a survey method. There was a decline in the percentage of science and technology fields from a personal and social perspective in addition to a decline in the field of geology and space science where their proportions in the whole textbooks were 5.2\%, $4.2 \%$ and 3.5\% respectively. Shalabi (2014) evaluated the content of existing science textbooks at primary stage in light of the provision of the $21^{\text {st }}$ century skills. It also studied how such skills can be integrated into science curriculum. Then, Delphi method was used during three rounds where the views of ten experts were investigated. Six science textbooks, in the basic education, were analyzed using the content analysis method. Findings revealed a clear shortage of the required skills for the $21^{\text {st }}$ century. At the end, a framework of three groups of skills was proposed. Foudeh and Ghanem (2015) investigated how countries all over the world can achieve comprehensive and sustainable development in light of current global strategies of science, technology and innovation. The proposed perspective, at the end of the study, consisted of a set of areas like the foundations of science curriculum development in the basic education stage, its objectives, and how it should be evaluated.

In conclusion, previous research and studies have shown that science curriculum, at the primary stage, does not pay much attention to treatment of scientific topics (Mohammed, 2012) and (Al Ghamdi, 2012), besides the lack of skills of $21^{\text {st }}$ century skills (Shalabi, 2014). Therefore, studies such as Al Ghayyadh (2003), Mohammed (2012) (Shalabi, 2014) and (Foudeh \& Ghanem, 2015) have provided visions for developing science curriculum but have not linked science curriculum to any developmental plans as did the Kingdom's Vision for 2030. Therefore, the present study is the first to do so.

\section{Methodology}

The descriptive survey approach was used to determine the provision reality of the requirements of Saudi Arabia's Vision for 2030 to develop the science curriculum for the upper primary grades from the experts' viewpoint. Delphi Method, where a set of experts respond to a set of survey questions, almost a questionnaire was used. After a set of repeated rounds, respondents are assumed to come up to a convergence of viewpoints and results (Sarhan, 2008). The use of Delphi Method rounds makes experts' face-to-face meetings not necessary (Feleeh \& Al Thaki, 2003; Zein Al Dine, 2013).

\subsection{Population}

The population of the present study consisted of four main groups. All Saudi faculty members specializing in curriculum and methods of teaching science constituted the first group. All faculty members of science mainly chemistry, physics and biology constituted the second one. The third group consisted of all educational supervisors of science teachers, whereas the last group included all schoolteachers of science at public schools in Saudi Arabia.

\subsection{Sample}

Random samples of the study population groups were selected. The first sample group consisted of experienced Saudis who were faculty members of curricula and methods of instruction curricula. The second sample group included faculty members of science teaching. The third sample group involved schoolteachers of science while 
educational supervisors of science teachers constituted the fourth sample group. Participants' total number was (28) educational experts. Faculty members were chosen from Um Al-Qura University, Northern Boarders University, Al-Jouf University, and University of Tabuk. Science teachers and educational supervisors, on the other hand, were selected from the regions of Makkah, Tabuk, and the Northern Boarders. Participants' views were investigated regarding the provision of the requirements of the Kingdom's Vision for 2030 to develop the science curriculum. In addition, participants' views were analyzed to identify their perspectives related to how science curriculum can be developed to meet the requirements of the kingdom's vision. The selection of only Saudi experts was because they were more familiar with the development of science curriculum in the primary level and the Kingdom's Vision for 2030 in development. Table (1) shows experts' numbers, specialties, and selection criteria.

Table 1. Experts' numbers, specialties and selection criteria

\begin{tabular}{cllll}
\hline Category & Specialty & Selection Criteria & N. \\
\hline .1 & $\begin{array}{l}\text { Faculty members of curricula } \\
\text { and methods of instruction }\end{array}$ & $\begin{array}{l}\text { An experience in practical education and } \\
\text { curriculum design and development. }\end{array}$ & 7 \\
.2 & $\begin{array}{l}\text { Faculty members of science } \\
\text { teaching } \\
\text { Physics-Biology) }\end{array}$ & $\begin{array}{l}\text { An experience in curriculum design, } \\
\text { development and appropriate scientific } \\
\text { teaching materials for primary stage. }\end{array}$ & 7 \\
.3 & $\begin{array}{l}\text { Educational supervisors of } \\
\text { science schoolteachers } \\
\text { Science schoolteachers }\end{array}$ & $\begin{array}{l}\text { An experience in education supervision not } \\
\text { less than five years. }\end{array}$ & 7 \\
An experience in teaching science for the $5^{\text {th }}$ & 7 \\
and 6 $6^{\text {th }}$ graders not less than ten years. & \\
\hline Total & & & $\mathbf{2 8}$ \\
\hline
\end{tabular}

Table (1) shows that seven experts were in each group. Numbers in all groups were equal to guarantee the relative effect of each category on the results of the sample as a whole. All participants were consulted to participate in the study. They were all informed that their responses would be confidential for the sake of objectivity and for the sake of making no influence on their opinions despite the spatial dimension until a consensus is made. Experts of extremist views were requested to justify their responses (Al Johani, 2009).

\subsection{Study Instrument}

The questionnaire, as the main study instrument, was used to address the provision reality of the requirements of the Kingdom's Vision for 2030 in development in the science curriculum for the upper primary grades. It was developed, after a careful revision of the kingdom's vision for 2030. Then it was administered to all participant experts during three rounds regarding to Delphi method. Requirements of the Kingdom's Vision, included in the developed questionnaire, were distributed to four main fields in science curriculum for upper primary grades namely; aims, content, methods of teaching, and evaluation. Flexibility was accounted for when choosing and writing the questionnaire items.

\subsection{Validity of the Study Instrument}

\subsubsection{Validity of Arbitrators}

After developing the questionnaire in its preliminary version, it was presented to six arbitrators who were faculty members, educational supervisors, and science schoolteachers. All were requested to ascertain the degree of relevance of each item to its main field. They were also asked to check items' clarity and language. At the end, some items were deleted and others were added.

\subsubsection{Validity of the Internal Consistency of the Study Instrument}

The internal consistency of the questionnaire was applied to a pilot sample of (15) experts of faculty members, educational supervisors, science schoolteachers for validation. Validation coefficients of the four fields to the whole degree were relatively high. They ranged between $(0.71)$ and $(0.91)$. All of them were statistically significant at $(\alpha=0.05)$.

\subsubsection{Reliability of the Study Instrument}

Reliability of the questionnaire was calculated using Cronbach alpha. Reliability coefficient for the questionnaire's items as a whole was (0.83) indicating that results obtained via the application of such questionnaire will be reliable 
and generalizable.

\subsubsection{Responding to the Items of the Questionnaire}

Five-dimension Likert scale was used to identify the participants' responses. Responses to each item were "Available to a very high degree", "Available to a high degree", "Available to a moderate degree", Available to a little degree", and "Not available at all". Degrees attached to each response were "5, 4, 3, 2, and 1 respectively. Therefore, items that had mean scores ranging between $(\mathrm{M}=5.00)$ and $(\mathrm{M}=4.21),(\mathrm{M}=4.20)$ and $(\mathrm{M}=3.41),(\mathrm{M}=3.40)$ and $(\mathrm{M}=2.61),(\mathrm{M}=2.60)$ and $(\mathrm{M}=1.81)$ and $(\mathrm{M}=1.80)$ and $(\mathrm{M}=1.00)$ were classified "Very Available", "Available", "Available to a moderate degree", "Available to a little degree", and "Not available at all" respectively.

\section{Results and Discussion}

\subsection{Results Related to the First Question}

To answer the first question that stated, "How do the educational experts perceive the provision reality of the requirements of Saudi Arabia's Vision for 2030 in development in the science curriculum for the upper primary grades?" responses' mean scores, standard deviations and ranks were used. Results are shown in Table (2).

Table 2. Mean scores, standard deviations and ranking for experts' responses

\begin{tabular}{cllll}
\hline Study field & M. & SD. & Response & Rank \\
\hline $\begin{array}{r}\text { Content of the science } \\
\text { curriculum }\end{array}$ & 2.59 & 0.20 & Available to a little degree & 1 \\
$\begin{array}{c}\text { Aims of the science } \\
\text { curriculum }\end{array}$ & 2.54 & 0.46 & Available to a little degree & 2 \\
$\begin{array}{c}\text { Evaluation of the science } \\
\text { curriculum }\end{array}$ & 2.52 & 0.26 & Available to a little degree & 3 \\
$\begin{array}{c}\text { Methods of teaching the } \\
\text { science curriculum }\end{array}$ & 2.38 & 0.34 & Available to a little degree & 4 \\
\hline Average & $\mathbf{2 . 5 2}$ & $\mathbf{0 . 1 7}$ & Available to a little degree
\end{tabular}

Table (2) shows clearly that the degree of the provision of the requirements of the Kingdom's vision for 2030 in development in the science curriculum for the upper primary grades $(M=2.52)$ and $(S D=0.17)$ was "Available to a little degree". On the other hand, participants' responses to each field reveal that the provision degrees of the vision's requirements in the four study fields were "Available to a little degree". The highest mean score $(M=2.59)$ and $(S D=0.20)$ was for the "Content of the science curriculum" field. The "Goals of the science curriculum" field $(M=2.54)$ and $(\mathrm{SD}=0.46)$ was in the second rank. In the third rank $(M=2.52)$ and $(S D=0.26)$ was the field of "evaluation of the science curriculum". Whereas, the field of the "Methods of teaching the science curriculum" $(M=2.38)$ and $(S D=0.34)$ was in the fourth rank with the least responses' mean score.

This result, in accordance to the level of provision of the requirements of the Kingdom's Vision for 2030 in development, corroborates the findings of Mohammed (2012) and Al Ghamdi (2012) regarding the inability of the science curriculum for the primary stage to address the scientific topics. The result also supports the finding of Shalabi (2014) in accordance to the low inclusion level of the $21^{\text {st }}$ century skills in the science curriculum.

To sum up, the result of the present study can be attributed to the lack of attention paid by the curriculum designers, experts and specialists to the issue of developing the science curriculum for the upper primary grades. In addition, findings of research and studies have almost agreed on the deficiency of the science curriculum at both Arabic and international levels to prepare learners for life and work in the $21^{\text {st }}$ century (Shalabi, 2014). This result also rings the bell to develop the science curriculum for the upper primary grades in terms of its aims, content, methods of teaching and evaluation. That is, science curriculum is in an urgent need to be modified to meet the demands of the Kingdom's Vision for 2030 in development. Therefore, Saudi Ministry of Education should adopt quickly a new and different system that focuses on quality not quantity of the science curriculum. Furthermore, science curriculum should be compatible with present era requirements and empower learners to achieve the developmental and economic goals (Al Ali, 2016).

\subsection{Results Related to the Second Question}

To answer the second question that stated, "What perspective do the educational experts propose to develop the science curriculum for the upper primary grades to meet the requirements of Saudi Arabia's Vision for 2030 in 
development?" the developed questionnaire was administered to check participants' viewpoints. It consisted of all items about the visions' requirements that were believed to be "Available to a little degree" in the science curriculum of the upper primary grades. Not all items that were believed to be "Available to a very high degree, Available to a high degree, and Available to a moderate degree" were included in the questionnaire. Experts were to choose the responses to the requirements that fulfilling them, as they believed in science curriculum, will achieve the kingdom's vision for 2030 in development. Through the three rounds, frequencies; proportions; mean scores and standard deviations of the educational experts' responses were extracted. After that, responses were ranked in a descending order according to their mean scores.

\subsubsection{Round One}

Implementation of round one started on September 9, 2017 and ended on October 1, 2017. The aim of this round was to identify the respondents' viewpoints regarding the provision of a set of characteristics for developing upper primary grades' science curriculum. Experts' responses showed that some statements were highly needed whereas other statements were not so. Agreement levels towards this degree of importance ranged between "strongly agree and strongly disagree". Therefore, statements that were of "strongly disagree" rank like, "the aims of the curriculum harmonize between the outcomes of the educational system and the needs of labor market", "the methods of teaching the curriculum focus on the continuous training" and "the content of the curriculum links pupils to healthy, environmental and nutritional variables", were completely deleted. However, statements like "the curriculum enhances the pupils' national identity" and "the curriculum enhances pupils' hygienic life style" were added. Statements like "evaluating the curriculum provides a database to monitor the academic study at all stages" and "the teaching methods of the curriculum are appropriate for all pupils" were changed to "the curriculum provides a database to monitor students' learning process" and "the teaching methods of the curriculum accounts for the individual differences among pupils" respectively.

\subsubsection{Round Two}

Round two started on October 5, 2017 and ended on October 19, 2017. The main aim of this round was to check how important the provided characteristics respondent experts have strongly agreed upon in round one were. Therefore, they were requested again to respond to all items involved in the delivered questionnaire. Respondents were allowed the opportunity to suggest any modification.

Table 3. Frequencies mean scores, standard deviations and ranks of experts' responses in round two

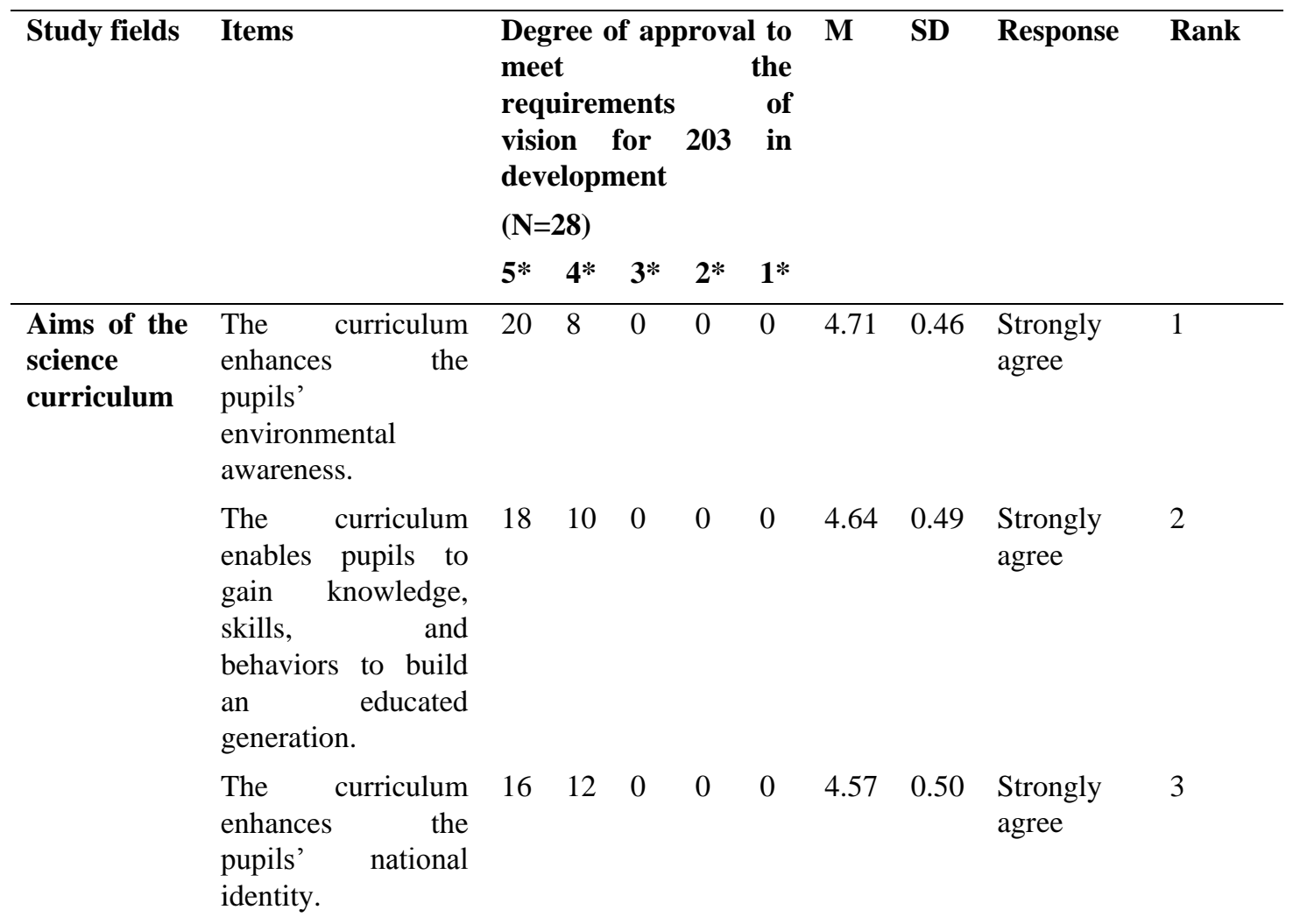




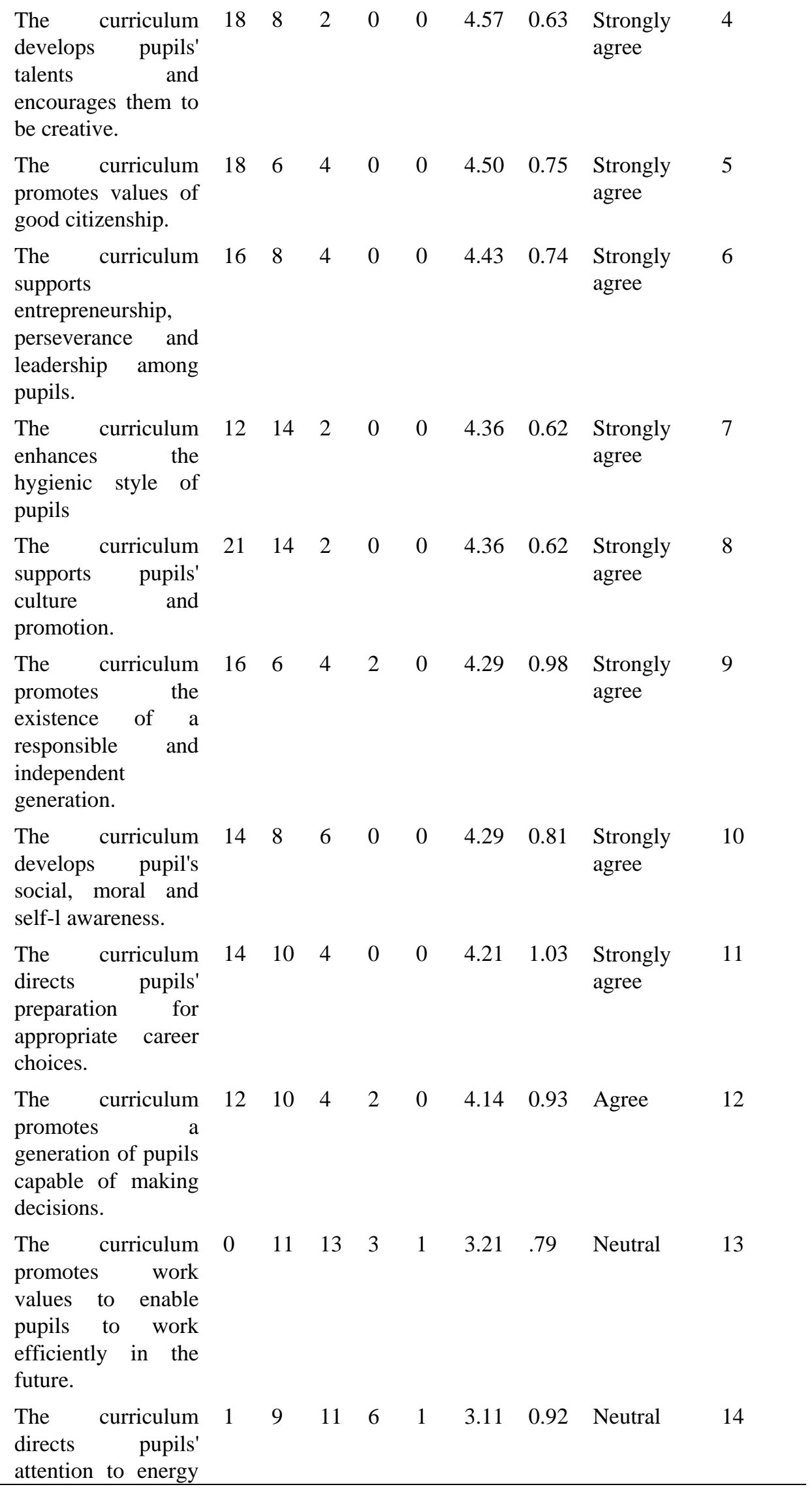


topics.

\begin{tabular}{|c|c|c|c|c|c|c|c|c|c|c|}
\hline \multirow[t]{10}{*}{$\begin{array}{l}\text { Content of } \\
\text { the science } \\
\text { curriculum }\end{array}$} & $\begin{array}{l}\text { The curriculum } \\
\text { emphasizes the } \\
\text { pupils' basic skills }\end{array}$ & 16 & 12 & 0 & 0 & 0 & 4.57 & 0.50 & $\begin{array}{l}\text { Strongly } \\
\text { agree }\end{array}$ & 1 \\
\hline & $\begin{array}{l}\text { The curriculum } \\
\text { includes } \\
\text { consumption } \\
\text { patterns, lifestyles, } \\
\text { and their role in } \\
\text { improving quality } \\
\text { of life. }\end{array}$ & 18 & 8 & 2 & 0 & 0 & 4.57 & 0.63 & $\begin{array}{l}\text { Strongly } \\
\text { agree }\end{array}$ & 2 \\
\hline & $\begin{array}{l}\text { The curriculum } \\
\text { links students to } \\
\text { healthy and food } \\
\text { aspects }\end{array}$ & 18 & 8 & 2 & 0 & 0 & 4.57 & 0.63 & $\begin{array}{l}\text { Strongly } \\
\text { agree }\end{array}$ & 3 \\
\hline & $\begin{array}{l}\text { The curriculum } \\
\text { explains the } \\
\text { economically useful } \\
\text { national scientific } \\
\text { projects such as } \\
\text { vision for } 2030 \text {. }\end{array}$ & 16 & 10 & 0 & 2 & 0 & 4.43 & 0.84 & $\begin{array}{l}\text { Strongly } \\
\text { agree }\end{array}$ & 4 \\
\hline & $\begin{array}{l}\text { The curriculum } \\
\text { contains topics } \\
\text { related to } \\
\text { sustainable } \\
\text { development and } \\
\text { clean environment. }\end{array}$ & 14 & 12 & 2 & 0 & 0 & 4.43 & 0.63 & $\begin{array}{l}\text { Strongly } \\
\text { agree }\end{array}$ & 5 \\
\hline & $\begin{array}{l}\text { The curriculum } \\
\text { contains practical } \\
\text { aspects of science in } \\
\text { industry, economy, } \\
\text { health and } \\
\text { environment. }\end{array}$ & 14 & 12 & 0 & 2 & 0 & 4.36 & 0.83 & $\begin{array}{l}\text { Strongly } \\
\text { agree }\end{array}$ & 6 \\
\hline & $\begin{array}{l}\text { The curriculum } \\
\text { deals } \\
\text { innovative } \\
\text { activities. }\end{array}$ & 16 & 10 & 0 & 0 & 2 & 4.36 & 1.06 & $\begin{array}{l}\text { Strongly } \\
\text { agree }\end{array}$ & 7 \\
\hline & $\begin{array}{l}\text { The curriculum } \\
\text { includes various } \\
\text { activities, such as } \\
\text { educational trips } \\
\text { and other } \\
\text { illustrations, etc. }\end{array}$ & 14 & 10 & 4 & 0 & 0 & 4.36 & 0.73 & $\begin{array}{l}\text { Strongly } \\
\text { agree }\end{array}$ & 8 \\
\hline & $\begin{array}{l}\text { The curriculum } \\
\text { includes clean } \\
\text { energy sources such } \\
\text { as sun, wind, etc. } \\
\text { and how to use them }\end{array}$ & 14 & 20 & 2 & 2 & 0 & 4.29 & 0.90 & $\begin{array}{l}\text { Strongly } \\
\text { agree }\end{array}$ & 10 \\
\hline & $\begin{array}{l}\text { The curriculum } \\
\text { includes scientific } \\
\text { knowledge and its } \\
\text { applications to }\end{array}$ & 12 & 10 & 6 & 0 & 0 & 4.21 & 0.79 & $\begin{array}{l}\text { Strongly } \\
\text { agree }\end{array}$ & 11 \\
\hline
\end{tabular}


preserve

environment

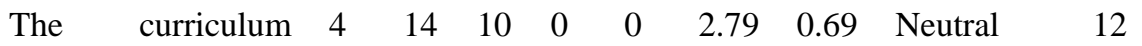

makes pupils ware

of the importance of

scientific culture

and its role in the

economic

development

The curriculum

makes pupils aware

of science and

technology role in

achieving the

developmental

goals.

\begin{tabular}{|c|c|c|c|c|c|c|c|c|c|c|}
\hline \multirow[t]{5}{*}{$\begin{array}{l}\text { Methods of } \\
\text { teaching the } \\
\text { science } \\
\text { curriculum }\end{array}$} & $\begin{array}{l}\text { The curriculum } \\
\text { provides new } \\
\text { strategies that focus } \\
\text { on skills' } \\
\text { development }\end{array}$ & 16 & 10 & 2 & 0 & 0 & 4.50 & 0.64 & $\begin{array}{l}\text { 1strongly } \\
\text { agree }\end{array}$ & 1 \\
\hline & $\begin{array}{l}\text { The curriculum } \\
\text { focuses on the } \\
\text { practical aspects. }\end{array}$ & 18 & 6 & 4 & 0 & 0 & 4.50 & 0.75 & $\begin{array}{l}\text { Strongly } \\
\text { agree }\end{array}$ & 2 \\
\hline & $\begin{array}{l}\text { The curriculum } \\
\text { accounts for the } \\
\text { individual } \\
\text { differences among } \\
\text { pupils. }\end{array}$ & 16 & 10 & 0 & 2 & 0 & 4.43 & 0.84 & $\begin{array}{l}\text { Strongly } \\
\text { agree }\end{array}$ & 3 \\
\hline & $\begin{array}{l}\text { The curriculum } \\
\text { enhances the } \\
\text { educational } \\
\text { partnership with the } \\
\text { private sector in } \\
\text { delivering programs } \\
\text { and events. }\end{array}$ & 12 & 14 & 2 & 0 & 0 & 4.36 & 0.62 & $\begin{array}{l}\text { Strongly } \\
\text { agree }\end{array}$ & 4 \\
\hline & $\begin{array}{l}\text { The curriculum } \\
\text { involves the family } \\
\text { in the educational } \\
\text { process. }\end{array}$ & 14 & 10 & 4 & 0 & 0 & 4.21 & 1.03 & $\begin{array}{l}\text { Strongly } \\
\text { agree }\end{array}$ & 5 \\
\hline \multirow[t]{3}{*}{$\begin{array}{l}\text { Evaluation } \\
\text { of the } \\
\text { science } \\
\text { curriculum }\end{array}$} & $\begin{array}{l}\text { The curriculum } \\
\text { provides objective } \\
\text { measurement } \\
\text { indicators that } \\
\text { reflect pupils' } \\
\text { performance. }\end{array}$ & 16 & 10 & 0 & 2 & 0 & 4.43 & 0.84 & $\begin{array}{l}\text { Strongly } \\
\text { agree }\end{array}$ & 1 \\
\hline & $\begin{array}{l}\text { The curriculum } \\
\text { improves the quality } \\
\text { of the learning } \\
\text { process outputs. }\end{array}$ & 16 & 10 & 0 & 2 & 0 & 4.43 & 0.84 & $\begin{array}{l}\text { Strongly } \\
\text { agree }\end{array}$ & 2 \\
\hline & The curriculum & 16 & 10 & 0 & 2 & 0 & 4.43 & 0.84 & Strongly & 3 \\
\hline
\end{tabular}




\begin{tabular}{|c|c|c|c|c|c|c|c|c|}
\hline $\begin{array}{l}\text { involves } \\
\text { elements } \\
\text { components. }\end{array}$ & & & & & & & & agree \\
\hline $\begin{array}{l}\text { The curriculum } \\
\text { provides a database } \\
\text { to monitor students' } \\
\text { learning process. }\end{array}$ & 12 & 14 & 2 & 0 & 0 & 4.36 & 0.62 & $\begin{array}{l}\text { Strongly } \\
\text { agree }\end{array}$ \\
\hline $\begin{array}{l}\text { The curriculum is } \\
\text { connected } \\
\text { meeting to } \\
\text { requirements the } \\
\text { society. }\end{array}$ & 16 & 8 & 2 & 2 & 0 & 4.29 & 1.12 & $\begin{array}{l}\text { Strongly } \\
\text { agree }\end{array}$ \\
\hline $\begin{array}{l}\text { The curriculum } \\
\text { meets the } \\
\text { requirements of } \\
\text { development. }\end{array}$ & 16 & 2 & 10 & 0 & 0 & 4.21 & 0.96 & $\begin{array}{l}\text { Strongly } \\
\text { agree }\end{array}$ \\
\hline $\begin{array}{l}\text { The curriculum is } \\
\text { continuous. }\end{array}$ & 0 & 10 & 12 & 4 & 2 & 3.07 & 0.90 & Neutral \\
\hline
\end{tabular}

$5^{*}=$ strongly agree $\quad 4^{*}=$ agree $3 *=$ neutral $\quad 4^{*}=$ disagree $\quad 5^{*}=$ strongly disagree

Table (3) shows that fourteen statements were in the first field of the study namely, "the aims of the science curriculum of the upper primary grades". Mean scores of experts' viewpoints were ranging between "strongly agree" and "neutral". Statements that showed experts' strong agreement were (11) statements. Their mean scores were ranging between $(M=4.71)$ and $(M=4.21)$. Only one statement $(M=4.14)$ was in the "agree" category. Two more statements, whose mean scores were $(M=3.21)$ and $(M=3.11)$, were in the "neutral" category.

Thirteen statements constituted the second field namely "the content of the science curricula for the upper primary grades". Means scores were ranging between "strongly agree" and "neutral". Eleven (11) statements whose mean scores were ranging between $(M=4.57)$ and $(M=4.21)$, were in the "strongly agree" category. However, two statements $(M=2.79)$ and $(M=2.71)$ were in the "neutral" category. With regard to field three that involved five statements to study experts' perceptions about the methods of teaching the science curriculum, all experts' responses mean scores were in the "strongly agree" category and were ranging between $(M=4.50)$ and $(M=4.21)$. On the other hand, the last field consisted of seven statements to distinguish the experts' opinions regarding the criteria for evaluating the science curricula. All mean scores ranged between "strongly agree" and "neutral" among which six statements were in the "strongly agree" category $(M=4.43)$ and $(M=4.21)$ and one statement $(M=3.07)$ was in the "neutral" category.

For the sake of identifying the main and powerful characteristics in the science curriculum, it was decided to keep the statements that were highly agreed upon by experts. All statements in the "strongly agree" and "agree" categories were considered important to be presented in any proposal for developing the science curriculum. Some modifications were made in light of the experts' views and recommendations, for instance, "the curriculum promotes a generation of pupils capable of making decisions" statement was changed to "the curriculum promotes a generation of pupils capable of making decisions in the future". In addition, "the curriculum promotes work values to enable pupils to work efficiently in the future" statement was changed to "the curriculum develops the pupils' professional thinking" and "The curriculum directs pupils' attention to energy topics" to "the curriculum directs pupils' attention to the ideal use of energy". Statements like "the curriculum makes pupils ware of the importance of scientific culture and its role in the economic development, and "the curriculum makes pupils aware of science and technology role in achieving the developmental goals" were replaced by "the curriculum links science and technology by achievement of the economic and developmental aims" statement. In addition, the word "continuous" in "the curriculum is continuous" statement was changed to "the curriculum is characterized by continuity". All Statements in the "neutral" category were reconsidered, too.

\subsubsection{Round Three}

Round three started on October 22, 2017 and ended on November 9, 2017. Results are presented in Table (4). The main aim of such a round was to confirm the importance of all statements delivered to experts after modifications made during the first and second rounds. Because of this round, statements that were "strongly agreed upon" were 
determined as the main characteristics that should be provided by the proposed science curriculum in the present study.

Table 4. Frequencies mean scores, standard deviations and ranks of experts' responses in round three

\begin{tabular}{|c|c|c|c|c|c|c|c|c|c|c|}
\hline \multirow[t]{2}{*}{ Study fields } & \multirow[t]{2}{*}{ Items } & \multicolumn{5}{|c|}{$\begin{array}{l}\text { Degree of approval to } \\
\text { meet the } \\
\text { requirements of the } \\
\text { vision for } 2030 \text { in } \\
\text { development }\end{array}$} & \multirow[t]{2}{*}{$\mathbf{M}$} & \multirow[t]{2}{*}{ SD } & \multirow[t]{2}{*}{ Response } & \multirow[t]{2}{*}{ Rank } \\
\hline & & $5 *$ & $4 *$ & $3 *$ & $2 *$ & $1 *$ & & & & \\
\hline \multirow{10}{*}{$\begin{array}{l}\text { Aims of the } \\
\text { science } \\
\text { curriculum }\end{array}$} & $\begin{array}{l}\text { The curriculum } \\
\text { enhances the pupils' } \\
\text { national identity. }\end{array}$ & 26 & 2 & 0 & 0 & 0 & 4.92 & 0.26 & $\begin{array}{l}\text { Strongly } \\
\text { agree }\end{array}$ & 1 \\
\hline & $\begin{array}{l}\text { The curriculum } \\
\text { promotes values of } \\
\text { good citizenship. }\end{array}$ & 24 & 4 & 0 & 0 & 0 & 4.86 & 0.36 & $\begin{array}{l}\text { Strongly } \\
\text { agree }\end{array}$ & 2 \\
\hline & $\begin{array}{l}\text { The curriculum } \\
\text { enhances the pupils' } \\
\text { environmental } \\
\text { awareness. }\end{array}$ & 23 & 5 & 0 & 0 & 0 & 4.82 & 0.39 & $\begin{array}{l}\text { Strongly } \\
\text { agree }\end{array}$ & 3 \\
\hline & $\begin{array}{l}\text { The curriculum enables } \\
\text { pupils to gain } \\
\text { knowledge, skills, and } \\
\text { behaviors to build an } \\
\text { educated generation. }\end{array}$ & 22 & 6 & 0 & 0 & 0 & 4.79 & 0.42 & $\begin{array}{l}\text { Strongly } \\
\text { agree }\end{array}$ & 4 \\
\hline & $\begin{array}{l}\text { The curriculum } \\
\text { supports } \\
\text { entrepreneurship, } \\
\text { perseverance and } \\
\text { leadership among } \\
\text { pupils. }\end{array}$ & 21 & 7 & 0 & 0 & 0 & 4.75 & 0.44 & $\begin{array}{l}\text { Strongly } \\
\text { agree }\end{array}$ & 5 \\
\hline & $\begin{array}{l}\text { The curriculum } \\
\text { promotes the existence } \\
\text { of a responsible and } \\
\text { independent } \\
\text { generation. }\end{array}$ & 20 & 8 & 0 & 0 & 0 & 4.71 & 0.46 & $\begin{array}{l}\text { Strongly } \\
\text { agree }\end{array}$ & 6 \\
\hline & $\begin{array}{l}\text { The curriculum } \\
\text { develops pupil's social, } \\
\text { moral and self- } \\
\text { awareness. }\end{array}$ & 19 & 9 & 0 & 0 & 0 & 4.67 & 0.48 & $\begin{array}{l}\text { Strongly } \\
\text { agree }\end{array}$ & 7 \\
\hline & $\begin{array}{l}\text { The curriculum } \\
\text { develops pupils' talents } \\
\text { and encourages them to } \\
\text { be creative. }\end{array}$ & 18 & 10 & 0 & 0 & 0 & 4.64 & 0.49 & $\begin{array}{l}\text { Strongly } \\
\text { agree }\end{array}$ & 8 \\
\hline & $\begin{array}{l}\text { The curriculum } \\
\text { enhances the hygienic } \\
\text { style of pupils }\end{array}$ & 17 & 11 & 0 & 0 & 0 & 4.61 & 0.50 & $\begin{array}{l}\text { Strongly } \\
\text { agree }\end{array}$ & 9 \\
\hline & $\begin{array}{l}\text { The curriculum } \\
\text { supports pupils' culture } \\
\text { and promotion. }\end{array}$ & 16 & 12 & 0 & 0 & 0 & 4.57 & 0.50 & $\begin{array}{l}\text { Strongly } \\
\text { agree }\end{array}$ & 10 \\
\hline
\end{tabular}


$\begin{array}{lllllllllll}\text { The } & \text { curriculum } & 15 & 13 & 0 & 0 & 0 & 4.53 & 0.51 & \text { Strongly } & 11\end{array}$

promotes a generation

of pupils capable of making decisions in the future.

The curriculum directs pupils' preparation for appropriate career choices.

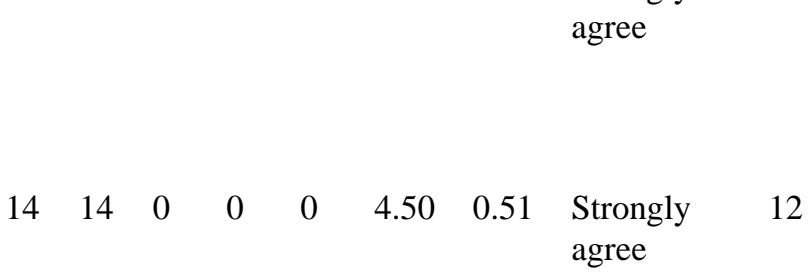

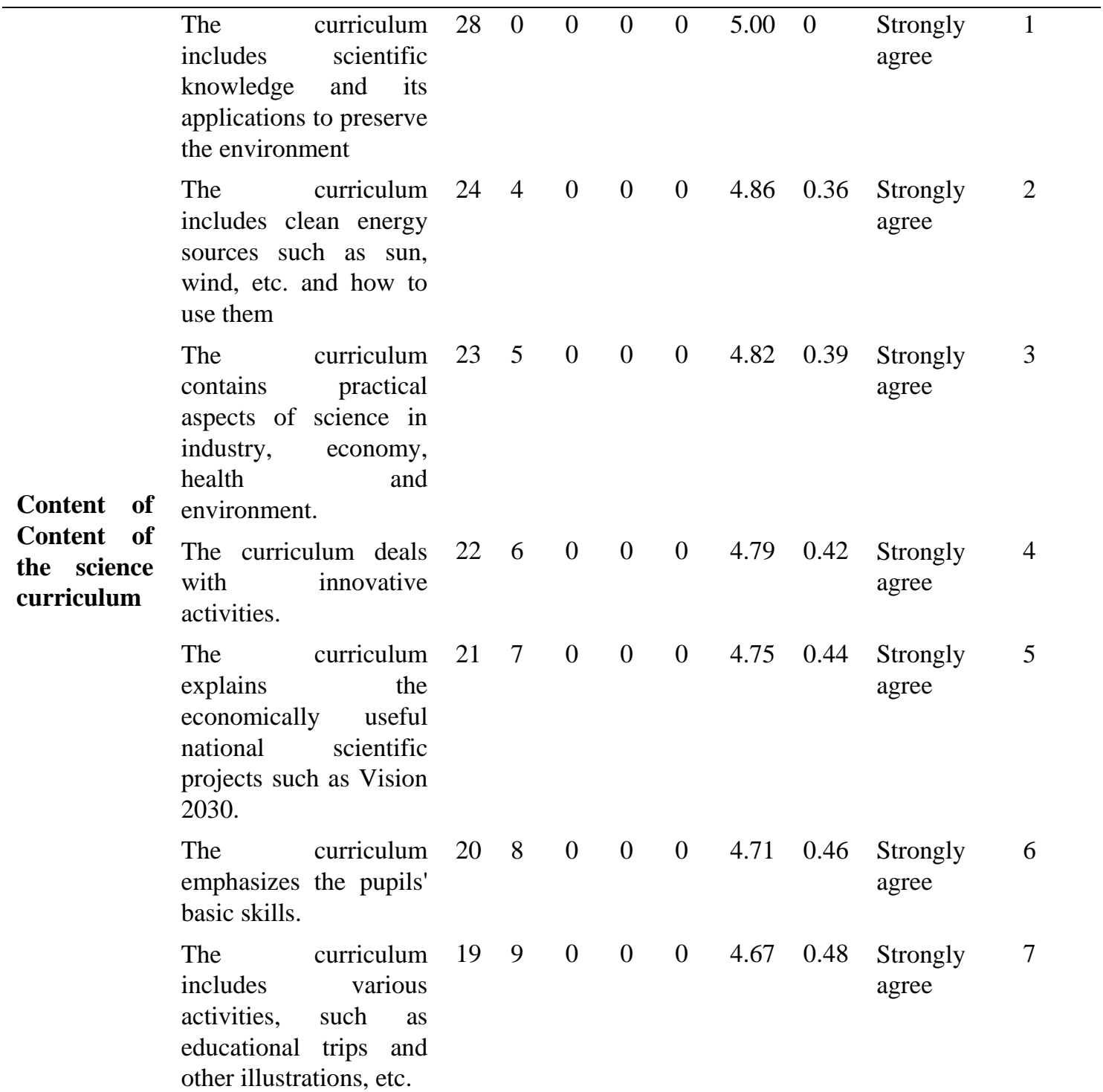


$\begin{array}{lllllllllll}\text { The } & \text { curriculum } & 18 & 10 & 0 & 0 & 0 & 4.64 & 0.49 & \text { Strongly } & 8\end{array}$

includes consumption

patterns, lifestyles, and

their role in improving

quality of life.

The curriculum links students to health and food aspects

The curriculum contains topics related to sustainable development and clean environment.

The curriculum links science and technology by achievement of the economic and developmental goals

\begin{tabular}{|c|c|c|c|c|c|c|c|c|c|c|}
\hline \multirow{5}{*}{$\begin{array}{l}\text { Methods of } \\
\text { teaching } \\
\text { science } \\
\text { curriculum }\end{array}$} & $\begin{array}{l}\text { The curriculum } \\
\text { accounts for the } \\
\text { individual differences } \\
\text { among pupils. }\end{array}$ & 26 & 2 & 0 & 0 & 0 & 4.92 & 0.26 & $\begin{array}{l}\text { Strongly } \\
\text { agree }\end{array}$ & 1 \\
\hline & $\begin{array}{l}\text { The curriculum } \\
\text { provides new strategies } \\
\text { that focus on skills' } \\
\text { development }\end{array}$ & 24 & 4 & 2 & 0 & 0 & 4.86 & 0.36 & $\begin{array}{l}\text { Strongly } \\
\text { agree }\end{array}$ & 2 \\
\hline & $\begin{array}{l}\text { The curriculum focuses } \\
\text { on the practical aspects. }\end{array}$ & 23 & 5 & 0 & 0 & 0 & 4.82 & 0.39 & $\begin{array}{l}\text { Strongly } \\
\text { agree }\end{array}$ & 3 \\
\hline & $\begin{array}{l}\text { The curriculum } \\
\text { involves the family in } \\
\text { the educational process. }\end{array}$ & 22 & 6 & 0 & 0 & 0 & 4.79 & 0.42 & $\begin{array}{l}\text { Strongly } \\
\text { agree }\end{array}$ & 4 \\
\hline & $\begin{array}{l}\text { The curriculum } \\
\text { enhances the } \\
\text { educational partnership } \\
\text { with the private sector } \\
\text { in delivering programs } \\
\text { and events. }\end{array}$ & 18 & 10 & 0 & 0 & 0 & 4.64 & 0.49 & $\begin{array}{l}\text { Strongly } \\
\text { agree }\end{array}$ & 5 \\
\hline \multirow{3}{*}{$\begin{array}{l}\text { Evaluation } \\
\text { of the } \\
\text { science } \\
\text { curriculum }\end{array}$} & $\begin{array}{l}\text { The curriculum } \\
\text { provides objective } \\
\text { measurement indicators } \\
\text { that reflect pupils' } \\
\text { performance. }\end{array}$ & 24 & 4 & 0 & 0 & 0 & 4.86 & 0.36 & $\begin{array}{l}\text { Strongly } \\
\text { agree }\end{array}$ & 1 \\
\hline & $\begin{array}{l}\text { The curriculum } \\
\text { improves the quality of } \\
\text { the learning process } \\
\text { outputs. }\end{array}$ & 23 & 5 & 0 & 0 & 0 & 4.82 & 0.39 & $\begin{array}{l}\text { Strongly } \\
\text { agree }\end{array}$ & 2 \\
\hline & $\begin{array}{l}\text { The curriculum } \\
\text { provides a database to } \\
\text { monitor students' } \\
\text { learning process. }\end{array}$ & 22 & 6 & 0 & 0 & 0 & 4.79 & 0.42 & $\begin{array}{l}\text { Strongly } \\
\text { agree }\end{array}$ & 3 \\
\hline
\end{tabular}




\begin{tabular}{|c|c|c|c|c|c|c|c|c|c|}
\hline $\begin{array}{l}\text { The curriculum meets } \\
\text { the requirements of } \\
\text { development }\end{array}$ & 20 & 8 & 0 & 0 & 0 & 4.71 & 0.46 & $\begin{array}{l}\text { Strongly } \\
\text { agree }\end{array}$ & 4 \\
\hline $\begin{array}{l}\text { The curriculum } \\
\text { involves all elements } \\
\text { and components. }\end{array}$ & 19 & 9 & 0 & 0 & 0 & 4.67 & 0.48 & $\begin{array}{l}\text { Strongly } \\
\text { agree }\end{array}$ & 5 \\
\hline $\begin{array}{l}\text { The curriculum is } \\
\text { connected to meeting } \\
\text { the requirements of } \\
\text { society. }\end{array}$ & 15 & 13 & 0 & 0 & 0 & 4.53 & $\begin{array}{l}0-.5 \\
1\end{array}$ & $\begin{array}{l}\text { Strongly } \\
\text { agree }\end{array}$ & 6 \\
\hline $\begin{array}{l}\text { The curriculum } \\
\text { continuous. }\end{array}$ & 5 & 23 & 0 & 0 & 0 & 4.17 & 0.39 & Agree & 7 \\
\hline
\end{tabular}

$5^{*}=$ strongly agree $\quad 4^{*}=$ Agree $\quad 3^{*}=$ Neutral $\quad 4^{*}=$ Disagree $\quad 5^{*}=$ strongly disagree

Results in Table (4) show that experts' responses to the items included in the study instrument, i.e. the questionnaire, were of "Strongly agree" and "Agree" categories. Mean scores were ranging between $(M=5.00)$ and $(M=4.11)$. That is, the high level of experts' approval and consensus reveals the extent to which these items are important to be accounted for as the basis to develop the content of the science curriculum in accordance to the Kingdom's vision for 2030 in development.

In light of the literature related to the development of the content of the science curriculum and the negative results of the field survey of the experts' views regarding the provision of the requirements of the Kingdom's Vision for 2030 in development, it was important to think seriously of a new perspective that can meet these requirements. Viewpoints and consensus of a set of experts who participated in the present study over three rounds to develop the science curriculum of the upper primary grades in Saudi Arabia revealed that a new perspective can proposed.

\section{The Proposed Perspective to Develop the Science Curriculum of the Upper Primary Grades in accordance to the Kingdom's Vision 2030 in Development.}

\subsection{The Aims of the Science Curriculum in the Proposed Perspective}

The aims of the proposed science curriculum in light of Saudi Arabia's Vision for 2030 in development should:

1. enhance the pupils' national identity,

2. promote values of good citizenship,

3. enhance the pupils' environmental awareness,

4. enable pupils to gain knowledge, skills, and behavior to build an educated generation,

5. support entrepreneurship, perseverance and leadership among pupils,

6. promote the existence of a responsible and independent generation,

7. develop pupil's social, moral and self- awareness,

8. develop pupils' talents and encourages them to be creative,

9. enhance the hygienic style of pupils,

10. support pupils' culture and promotion,

11. promote a generation of pupils capable of making decisions in the future,

12. guide pupils' preparation for appropriate career choices,

13. develop the pupils' professional thinking, and

14. Direct pupils' attention to the ideal use of energy.

\subsection{The Content of the Science Curriculum in the Proposed Perspective}

The content of the proposed science curriculum in light of Saudi Arabia's vision for 2030 in development should:

1. include scientific knowledge and its applications to preserve the environment,

2. include clean energy sources such as sun, wind, etc. and how to use them,

3. contain practical aspects of science in industry, economy, health and environment, 
4. deal with innovative activities,

5. Explain the economically useful national scientific projects such as 2030 Vision.

6. emphasize the pupils' basic skills,

7. Include various activities, such as educational trips and other illustrations, etc...,

8. include consumption patterns and lifestyles and their role in improving quality of life,

9. link students to healthy and food aspects,

10. contain topics related to sustainable development and clean environment, and

11. Link science and technology to achievement of the economic and developmental goals.

\subsection{Teaching Methods of the Science Curriculum in the Proposed Perspective}

The teaching methods of the proposed science curriculum in light of Saudi Arabia's vision for 2030 in development should:

1. account for the individual differences among pupils,

2. provide new strategies that focus on skills' development,

3. focus on the practical aspects,

4. involve the family in the educational process, and

5. Enhance the educational partnership with the private sector in delivering programs and events.

\subsection{Evaluation of the Science Curriculum in the Proposed Perspective}

The means of evaluation in the proposed science curriculum in light of Saudi Arabia's vision for 2030 in development should:

1. provide objective measurement indicators that reflect pupils' performance,

2. improve the quality of the learning process outputs,

3. provide a database to monitor students' learning process,

4. meet the requirements of development,

5. involve all elements and components,

6. be connected to meeting the requirements of society, and

7. Be continuous.

\section{Conclusion}

Two main aims were the foundations of the present study. It, first, aimed to investigate the provision reality of all requirements needed to develop Saudi science curriculum for upper primary grades in light of the Kingdom's Vision for 2030. In the second place, the present study aimed to identify the participants' views regarding how science curriculum can be developed. that is what perspectives they provide to develop the science curriculum. Findings revealed that the current science curriculum lacks a set of important requirements. They also showed that, in light of the weak provision reality of these requirements in accordance to Saudi Arabia's Vision for 2030 in development, it is highly recommended to take advantage of the proposed perspective approved by all participant experts to develop the Saudi science curriculum for the upper primary grades.

\section{References}

Abdul Hamid, M. K. (2016). Developing Science Curriculum for the Preparatory Stage in Light of Science Criteria for the Next Generation (NGSS) and its Effectiveness in developing High-Order Thinking Skills, (Unpublished Ph.D. Thesis), Curriculum and Instruction Department, Faculty of Education, The Digital Library.

Abdul Salam, M. $\left(1431^{\mathrm{H}}\right)$. A Methodological Study for Teaching Thinking, available at: http://www.tarbyatona.net/include/plugins/article/article.php?a

Abdul Salam, M. A. (2006). Developing the Educational Curriculum to Fulfill the Requirements of Development and Meet the Challenges of Globalization, A Research Presented to the Conference of Qualitative Education and its Role in Human Development in the Era of Globalization, the $1^{\text {st }}$ Scientific Conference of the Faculty of Special Education - Mansoura University on April, 12-13, 271-310. 
Al Abdullah, I. Y. (2004). Educational Reform to Meet the Era Requirements and Future Challenges, Beirut: Prints Company for Distribution and Publishing.

Al Ali, A. (2016). The Gap between Education and Saudi Arabia's Vision for 2030, available at: http://www.alwatan.com.sa/Articles/Detail.aspx?ArticleId=30622

Al Bishr, M. \& Al Zahrani, S. (2004). Efforts of Saudi Arabia in the Field of Curriculum Development, a National Report Submitted to the Regional Workshop on Curriculum Development on December 11-12 in Muscat, Sultanate of Oman.

Al Ghamdi, M. (2012). Evaluation of the Content of the Developed Science Textbooks in the Lower Primary Grades in Light of Selected Criteria, (Unpublished MA, Thesis), Faculty of Education, Umm Al Qura University.

Al Ghayyadh, R. (2003). Developing Science Curriculum at the Primary Stage in Light of Modern Global Trends: Future Vision, (Unpublished Ph.D. Thesis), Department of Education, Faculty of Social Sciences, Imam Muhammad bin Saud Islamic University.

Al Johani, M. F. (2009). A Default Application of Delphi Method in Future Studies: Desired Arab Graduate: Exploring and Targeting, Knowledge Website: Available at: http://www.almarefh.net/show_content_sub.php

Al Oweysheq, N. \& Ahmad, N. (2010). The Project of Developing Math and Natural Sciences Curriculum: Translation and Harmonization of Global Chains, Paper Presented to The Development of Mathematics and Natural Sciences Curriculum symposium: Translation and Harmonization of Global Chains, College of Education, King Saud University on 26/12/2010.

Al Shaya, F. \& Al Aqeel, M. (2006). The Extent of Achieving the Content Standards in Kindergarten Textbooks for the Fourth Grade in the project of the National Science Education Standards (NSES) in the Content of Science Textbooks in Saudi Arabia. The 10 $0^{\text {th }}$ Scientific Conference: Challenges of the Present and Visions of the Future, Ain Shams University, I, 321-345.

Al Zubaidi, T. A. (2017). Science Teaching: between Reality and Hope, Arab Bureau of Education for the Gulf States, available at: http://www.abegs.org/

Al Zughaybi, M. (2011). The Reality of the Application of Mathematics and Science Project, a Paper Presented to the Symposium of the Project of Developing Mathematics and Natural Sciences Curricula in Public Education between Theory and Practice, on 3/4/2011 at the Faculty of Science, King Saud University.

Baltiyah, H. \& Metwally, A. (2000). Developing Exercises and Activities Associated with Mathematics Curriculum in the Primary Education in Light of Higher Order Thinking Skills, Egyptian Association of Mathematics Education, Journal of Mathematics Education, 3.

Bybee, R. W. (2010). The Teaching of Science $21^{\text {st }}$ Century Perspectives, National Science Teachers Associations, Arlington: NSTA Press.

Childs, P. E. (2015). Curriculum Development in Science: Past, Present and Future, National Centre for Excellence in Mathematics and Science Teaching and Learning, University of Limerick, Limerick, Ireland.

Curriculum Development Council \& the Hong Kong Examinations and Assessment Authority, (2014). Science Education Key Learning Area Combined Science Curriculum and Assessment Guide (Secondary4-6), Education Bureau HKSARG.

Feleeh, F. A. \& Al Thaki, A. A. (2003). Future Studies: An Educational Perspective, Amman: Dar Al Masirah.

Foudeh, I. M. \& Ghanem, T. S. (2015). Developing Science Curriculum for the Basic Education in Light of the Temporary Global Science and Technology Strategies and Innovation: a Proposed Vision, the Egyptian Society for Scientific Education, the $17^{\text {th }}$ Scientific Conference "Scientific Education and the Challenges of Technological Revolution", Ain Shams University, on August 11.

Fung, I., Townsend, M. \& Parr, J. (2004). Teachers Facilitating Critical Thinking in Students: the Search for a Model and a Method, Retrieved from: http://www.leeds.ac.uk/educol/documents/

Hassanein, B. (2014). Toward an Experiment to Develop Science Teaching in Pre-university Education. The $16^{\text {th }}$ Scientific Conference: Scientific Education is the Guideline for Excellence. Egyptian Association for Scientific Education, on August 9-10.

Jabir, W. A. (2005). General Teaching Methods: Planning and Educational Applications, Second Edition, And Amman: Dar Al-Fikr. 
Mohammed, R. (2012). Developing the Content of Science Curriculum for the Basic Education in Light of the Global Trends and Students' Scientific Interests, Journal of Arab Studies in Education and Psychology, 3 (30).

Sarhan, M. (2008). Development of a Proposed Instructional Model by the Use of Delphi Method as a Technical Method in Education, Journal of Educational Sciences, 1, 266-294.

Saudi Arabia's Vision for 2030, (2017). Education, available at http://vision2030 .gov.sa/ar/node/188

Sayyed, A. \& Salem, A. (2004). Evaluation in the Educational System, Riyadh: Al-Roshd Bookshop.

Seyyedezaie, S. H. \& Barani, G. (2013). Constructivism and Curriculum Development, International Journal of Basic Science \& Applied Research, 2(1), 62-67.

Shalabi, N. M. (2014). A Proposed Framework for Integrating Skills of the $21^{\text {st }}$ Century into Science Curriculum for the Basic Education in Egypt, International interdisciplinary Educational Journal, 3 (10), 1-33.

Shehata, H. (2003). Renewed Educational Horizons towards the Development of Education in the Arab World between Reality and Future, Cairo: The Egyptian Lebanese House.

Thijs, A. \& Akker, J. (2009). Curriculum in Development, Netherlands Institute for Curriculum Development (SLO), Enscheda, the Netherlands.

Younis, F. (2004). Curriculum: Foundations, Components, Organizations and Development, Amman: Dar Al Fikr.

Zaitoun, A. M. (2010). Contemporary Global Trends in Science Curriculum and its Teaching, Cairo: Dar Al Shorouq.

Zein Al Dine, M. M. (2013). Methods of Building the Proposed Perspective in the Scientific Dissertations, Department of Comparative Islamic Education at the Faculty of Education, Umm Al-Qura University, available at: https://khalil-alhadri.com/uploads/ 